\title{
Performance of maize single-crosses developed from populations improved by a modified reciprocal recurrent selection
}

\author{
Cláudio Lopes de Souza Jr. ${ }^{1 *}$; Sanzio Carvalho Lima Barrios²; Gustavo Vitti Moro² \\ ${ }^{1}$ USP/ESALQ - Depto. de Genética, C.P. 83 - 13400-970 - Piracicaba, SP - Brasil. \\ ${ }^{2}$ USP/ESALQ - Programa de Pós-Graduação em Genética e Melhoramento de Plantas. \\ *Corresponding author <clsouza@esalq.usp.br>
}

\begin{abstract}
Maize (Zea mays L.) elite inbred lines developed from pedigree programs tend to be genetically related. Therefore, it is necessary to incorporate unrelated inbreds to those programs to allow the continued release of outstanding single-crosses. The objectives of this research were to compare the usefulness of a modified reciprocal recurrent selection procedure (MRRS) to improve populations to be used as sources of elite inbreds and outstanding single-crosses to integrate pedigree programs, and to investigate the effects of selection on the relative contribution of general (GCA) and specific combining (SCA) abilities to the single-crosses variation. Eight and six $\mathrm{S}_{3}$ lines from populations IG-3-C1 and IG-4-C1, respectively, selected from the first cycle of the MRRS program were crossed in a partial-diallel mating design, and the 48 experimental and five commercial single-crosses were evaluated in six environments. Grain yield mean of the experimental singlecrosses $\left(9.57 \mathrm{t} \mathrm{ha}^{-1}\right)$ did not differ from the commercial single-crosses $\left(9.86 \mathrm{t} \mathrm{ha}^{-1}\right)$, and ten of the 48 experimental single-crosses could be released as cultivars because they compared favorably to the currently used singlecrosses. Thus, one cycle of the MRRS procedure improved efficiently the populations allowing the development of outstanding single-cross, but additional cycles of selection should be carried out since none of the experimental single-crosses outperformed the highest yielding commercial single-cross. The relative contribution of the GCA over SCA may have been affected by the MRRS, since the SCA was more important than GCA for some of the traits assessed.
\end{abstract}

Key words: diallel design, maize improvement, combining ability

\section{Performance de híbridos simples de milho desenvolvidos de populações melhoradas por seleção recorrente recíproca modificada}

\begin{abstract}
RESUMO: Linhagens elites de milho (Zea mays L.) desenvolvidas em programas genealógicos tendem a ser geneticamente relacionadas. Portanto, é necessário incorporar linhagens não relacionadas a estes programas para permitir a liberação contínua de híbridos simples superiores. Comparou-se a utilidade de um procedimento modificado de seleção recorrente recíproca (SRRM) em melhorar populações a serem utilizadas como fontes de linhagens elites e híbridos simples superiores para integrar os programas de melhoramento, e investigar os efeitos da seleção na contribuição relativa da capacidade geral (CGC) e da capacidade específica (CEC) de combinação para a variabilidade dos híbridos simples. Oito e seis linhagens $\mathrm{S}_{3}$ obtidas das populações IG-3-C1 e IG-4-C1, respectivamente, selecionadas do primeiro ciclo de SRRM, foram cruzadas no delineamento dialelo parcial e os 48 híbridos simples experimentais (HSE) e cinco híbridos simples comerciais (HSC) foram avaliados em seis ambientes. A média geral de produção de grãos dos HSE $\left(9.57 \mathrm{t} \mathrm{ha}^{-1}\right)$ não diferiu significativamente dos HSC $\left(9.86 \mathrm{t} \mathrm{ha}^{-1}\right)$, e dez dos 48 HSE poderiam ser liberados como cultivares, pois são comparáveis aos híbridos simples comerciais. Portanto, um ciclo de SRRM foi eficiente em melhorar as populações permitindo a produção de híbridos simples superiores, mas ciclos adicionais de seleção deverão ser conduzidos, pois nenhum dos HSE superou o híbrido simples comercial mais produtivo. As contribuições relativas da CGC e da CEC podem ter sido afetadas pela SRRM, uma vez que a CEC foi mais importante que a CGC para alguns caracteres avaliados. Palavras-chave: delineamento dialélico, melhoramento de milho, capacidade de combinação
\end{abstract}

\section{Introduction}

Populations developed from crosses of elite inbred lines, e.g., $\mathrm{F}_{2}$ 's or backcrosses, are, usually, the sources of inbred lines in commercial maize (Zea mays L.) breeding programs. The elite inbred lines developed from these populations are crossed to develop new populations, and then the elite inbred lines are recycled repetitively to assemble their favorable alleles in new inbred lines and hybrids (Hallauer, 1990; Bernardo, 2002). Al- though this procedure has been very effective to develop outstanding hybrids, in the long-term the recycled inbreds will become, to some extent, genetically related lessening the genetic variability of the breeding programs and, consequently, limiting the development of hybrids that outperform those ones already released (Smith, 1988; Yu and Bernardo, 2004).

Reciprocal recurrent selection (RRS) is a long-term cyclical breeding procedure outlined to improve population crosses, and reported results have shown that RRS 
has been very effective (Eyherabide and Hallauer, 1991; Souza Jr. and Pinto, 2000; Santos et al., 2005), and also the improved populations have been sources of elite inbreds and outstanding single-crosses (Hallauer et al., 1988; Betrán and Hallauer, 1996). The elite inbred lines from the RRS programs are unrelated to the inbreds developed from the recycling programs, and then they could be incorporated to these programs to maintain the rate of the development and release of new hybrids. Despite of its features, RRS procedure has seldom been used in commercial maize breeding programs mainly because of its long-term nature (Hallauer et al., 1988; Bernardo, 1996).

To be integrated into commercial hybrid breeding programs, RRS programs should use high selection intensity and evaluate testcrosses of $\mathrm{S}_{3}$ lines, instead of testcrosses of $S_{1}$ lines (Rezende and Souza Jr., 2000). High selection intensity will increase the frequency of favorable alleles at a higher rates per cycle, and the testcross of the $S_{3}$ lines will be an early test of their derived inbreds since the genetic correlation between testcrosses of $\mathrm{S}_{3}$ lines and their $\mathrm{S}_{7}$ counterparts is very high (Bernardo, 1991). One cycle of the modified (MRRS) procedure designed by Rezende and Souza Jr. (2000) increased grain yield by $16.7 \%$ and reduced significantly plant and ear heights. In a per cycle basis, this MRRS procedure increased grain yield at a higher rate than the 6.0\% to $7.0 \%$ reported for standard RRS programs where $10 \%$ to $20 \%$ as selection intensity and $\mathrm{S}_{1}$ lines for recombination were used (Eyherabide and Hallauer, 1991; Hallauer et al., 1988; Santos et al., 2007; Santos et al., 2005; Souza Jr. and Pinto, 2000). Then, the MRRS procedure was highly effective in improving the population cross performance in only one cycle of selection. Furthermore, there were no evidences that genetic variances and genetic correlations of the traits assessed changed significantly, indicating that further high-intensity selection cycles could be conducted.

Reciprocal recurrent selection was designed to exploit both general (GCA) and specific combining (SCA) abilities, which are related to additive and non-additive (dominance and epistatic) effects, respectively (Comstock et al., 1949). Several reports have showed that both GCA and SCA contribute similarly for grain yield variation, but for other traits such as grain yield components, days to flowering, plant height, and disease and insect resistance, GCA is more important than SCA for their variation (Hallauer and Miranda Filho, 1988). However, the relative contributions of these effects could be affected by recurrent selection programs (Doerksen et al., 2003; Santos et al., 2007). Since the RRS procedure presented by Rezende and Souza Jr. (2000) introduced new features, it is necessary to investigate whether it changed the relative contribution of GCA and SCA effects to the single-crosses variation.

Although the procedure presented by Rezende and Souza Jr. (2000) was highly efficient to improve population crosses, to be incorporated into commercial breed- ing programs the improved base populations should be sources of single-crosses that compare favorably or outperform the existing commercial single-crosses in few selection cycles. Thus, the objectives of this research were to (i) evaluate the efficiency of the modified RRS procedure in developing improved populations as sources of outstanding single-crosses, and (ii) verify whether the MRRS affected the relative contribution of general and specific combining abilities for the variation of the traits assessed.

\section{Material and Methods}

\section{Germplasm and selection procedures}

Early-flowering maize populations BR-105 and BR106 with orange flint and yellow dent kernels, respectively, allocated in different heterotic groups, and released by EMBRAPA/Milho e Sorgo (Souza Jr. et al., 1993) were used for this research. These populations are under high-intensity reciprocal recurrent program as already reported by Rezende and Souza Jr. (2000). Briefly, $400 \mathrm{~S}_{3}$ lines from each population were developed, and these lines were selected for high heritability traits as plant height, early-flowering, and disease and insect resistance. The $\mathrm{S}_{3}$ lines from the BR-105 population were testcrossed to the BR-106 population, and the $\mathrm{S}_{3}$ lines from the BR-106 population were testcrossed to the BR105 population. These testcrosses were evaluated in three locations with three replications per location. Based on grain yield, plant lodging and ear height, eight $(2.0 \%)$ and ten $(2.5 \%)$ testcrosses from populations BR-105 and BR106 were selected, and the recombination of the $S_{3}$ lines of each population gave rise to the IG-3-C1 and to the IG-4-C1 maize synthetics, respectively. Four-hundred S, lines from IG-3-C1 and $400 \mathrm{~S}_{3}$ lines from IG-4-C1 were developed and testcrossed to the reciprocal populations. The testcrosses were evaluated in three locations with three replications per location, and based on grain yield, plant lodging and plant height, a high selection intensity was applied on both populations: $2.0 \%$ (eight testcrosses selected) for the IG-3-C1 synthetic and 1.5\% (six testcrosses selected) for the IG-4-C1 synthetic. Then, the eight and six $\mathrm{S}_{3}$ lines related to the testcrosses selected from the IG-3-C1 and IG-4-C1 synthetics, respectively, were used for this research.

\section{Experimental procedures}

The eight and six $\mathrm{S}_{3}$ selected lines from IG-3-C1 and IG-4-C1 maize synthetics, respectively, were sib-mated and, subsequently, crossed in a partial-diallel mating design. The 48 experimental single-crosses (ESC) produced plus a commercial single-cross (CSC) BRS-1030 were allocated in a $7 \times 7$ lattice design; also, four CSC widely used by farmers in the southwest maize growing areas of Brazil from seed producers companies were allocated at the beginning of each replication, out of the lattice design, as checks. The experiments were evaluated in three Experimental Stations called Areão, Caterpillar and Anhembi, near the city of Piracicaba (22 ${ }^{\circ} 42^{\prime}$ S; 
$\left.47^{\circ} 37^{\prime} \mathrm{W}\right)$, São Paulo State, Brazil, in the growing seasons of 2005/2006 and 2006/2007. A combination of a location and a growing season was considered as an environment, and then, six environments with two replications per environment were used for evaluation. Plots were one row $4.0 \mathrm{~m}$ long spaced $0.8 \mathrm{~m}$ apart, and they were overplanted and thinned to 20 plants per plot $\left(62,500\right.$ plants $\left.\mathrm{ha}^{-1}\right)$. Data were recorded for grain yield $\left(\mathrm{t} \mathrm{ha} \mathrm{h}^{-1}\right)$, grain moisture $\left(\mathrm{g} \mathrm{kg}^{-1}\right)$, stand (plants per plot), plant height $(\mathrm{PH})$ and ear height $(\mathrm{EH})$ ( $\mathrm{cm}$ per plant), plant lodging $\left[\mathrm{PL}=\right.$ (root lodging + stalk lodging) $\left.\mathrm{plot}^{-1}\right]$, and number of ears per plot. Plant and ear heights were recorded on five competitive plants per plot, from the ground level to the collar of the flag leaf and to the uppermost ear node, respectively; and plot means were used for analyses. Grain yield (GY) of each plot was adjusted for average stand by covariance analyses and to grain moisture of $155 \mathrm{~g} \mathrm{~kg}^{-1}$. Prolificacy (PRO = ears per plant) was computed as the ratio number of ears per plot/stand, and adjusted to stand by covariance analysis; plant lodging was expressed as a percentage of the total plants per plot, and subsequently transformed to $(\mathrm{PL} \%+0.5)^{0.5}$; and ear placement $(\mathrm{EP})$ was computed per plot as the ratio ear height/plant height. GY was recorded in six environments, and the remaining traits in four environments; $\mathrm{PH}, \mathrm{EH}, \mathrm{PL}$ and $\mathrm{PRO}$ were not recorded in the Experimental Stations of Areão and Caterpillar in the 2005/2006 growing seasons.

\section{Statistical analyses}

Analysis of variance was computed for each environment, and the adjusted means and the effective error mean squares from each environment were used to compute the joint analysis of variance. Initially, error mean squares were submitted to Bartlett's test $(p \leq 0.05)$ of homogeneity (Sokal and Rohlf, 1995) and no significance were found for all traits evaluated. A mixed model was used since single-crosses were considered as fixed effects and environments as random effects in the mathematical model; therefore the entries $x$ environments means squares were used as denominators of the $F$ test for crosses in the joint analysis of variance. The PROC GLM from SAS software (SAS Institute, 2004) was used for all analyses.

The adjusted means from each environment were used to analyze the partial diallel design using the Griffing's (1956) concepts of general and specific combining abilities, in model I method 4, adapted to partial diallels (Geraldi and Miranda Filho, 1988) and expanded to multiple environments to include the interaction of main effects with environmental effects (Ferreira et al., 1993), as follows:

$Y_{i j k}=\mu+g_{i}+g_{j}+s_{i j}+\varepsilon_{k}+(g \varepsilon)_{i k}+(g \varepsilon)_{j k}+(s \varepsilon)_{i j k}+\bar{e}_{i j k}$

and $Y_{i j k}$ is the value of the experimental single-cross from the cross between the ith line from IG-3 synthetic and $\mathrm{j}$ th line from IG-4 synthetic in the $\mathrm{k} t h$ environment, $\mu$ is the general mean, $g_{i}\left(g_{j}\right)$ is the general combining ability of the ith or the jth line, $s_{i j}$ is the specific combining ability between the ith and jth lines, $\varepsilon_{k}$ is the effect of the $\mathrm{k} t h$ environment, $(g \varepsilon)_{i k},(g \varepsilon)_{j k}$ and $(s \varepsilon)_{i j k}$ are the corresponding interaction effects between the environment and the general and specific combining abilities, respectively, and $\bar{e}_{i j k}$ is the mean effective error. The sums of squares of the analyses of variances, the estimates of the general and specific combining abilities, as well as the standard errors of estimates of these parameters were computed from expressions given by Ferreira et al. (1993) which were derived from ordinary least squares procedures. $t$ tests were performed to test whether the estimates of $g_{i}\left(g_{j}\right)$ and of $s_{i j}$ differed significantly from zero as follows: $t_{\left(\alpha / 2 ; n_{1}\right)}=\hat{g}_{i} / \hat{s}\left(g_{i}\right)$ and $t_{\left(\alpha / 2 ; n_{2}\right)}=\hat{s}_{i j} / \hat{s}\left(s_{i j}\right)$; here $\hat{s}\left(g_{i}\right)$ and $\hat{s}\left(s_{i j}\right)$ are the standard errors of the GCA and SCA estimates; $n_{1}$ and $n_{2}$ are the degrees of freedom of the GCA $x$ environment and SCA $\times$ environment, respectively, and $\alpha=0.05$ and $\alpha=0.01$ were used. The sum of squares (SS) of the GCA and of the SCA sources of variation were used to compute the relative contribution of these effects to the variation of the ESC as: $\{\mathrm{SS}(\mathrm{GCA}) /[\mathrm{SS}(\mathrm{GCA})+\mathrm{SS}(\mathrm{SCA})]\} .100$ and $\{\mathrm{SS}(\mathrm{SCA}) /$ $[\mathrm{SS}(\mathrm{GCA})+\mathrm{SS}(\mathrm{SCA})]\} .100$; here $\mathrm{SS}(\mathrm{GCA})$ refers to the sum of GCA(IG-3) and GCA(IG-4) sums of squares.

\section{Results and Discussion}

\section{Means and analysis of variance}

The joint analysis of variance (not shown) detected highly significant differences $(p \leq 0.01)$ for entries for all traits evaluated. For entries $\mathrm{x}$ environments interaction highly differences were detected for grain yield (GY), plant lodging (PL) and ear placement (EP), whereas for plant height $(\mathrm{PH})$, ear height $(\mathrm{EH})$ and prolificacy $(\mathrm{PRO})$ no significant differences were detected. Thus, genetic variation was present among the ESC for all traits evaluated, and for only three of these traits the performances of the ESC differed significantly across environments. Average grain yield was $9.57 \mathrm{t} \mathrm{ha}^{-1}$ for the experimental (ESC) and $9.86 \mathrm{t} \mathrm{ha}^{-1}$ for the commercial (CSC) singlecrosses, and the coefficient of experimental variation was $12.06 \%$.

The GY means of the ESC ranged from 3.10 to 11.37 $\mathrm{t} \mathrm{ha}^{-1}$ and the means of the CSC ranged from 8.25 to 11.46 $\mathrm{t} \mathrm{ha}^{-1}$. ESC and CSC grain yield overall means did not differ significantly, and also the mean of the ten highest yielding ESC $\left(10.80 \mathrm{t} \mathrm{ha}^{-1}\right)$, which correspond to $20.83 \%$ of the ESC evaluated, did not differ from the highest yielding CSC (11.46 $\left.\mathrm{t} \mathrm{ha}^{-1}\right)$; but they differed from the lowest yielding CSC $\left(8.25 \mathrm{t} \mathrm{ha}^{-1}\right)$; and only one of the ESC presented lower grain yield than the lowest yielding CSC. For plant lodging (PL), the second trait most important in maize breeding programs, the ESC mean $\left(2.77 \%=1,731\right.$ plants $\left.\mathrm{ha}^{-1}\right)$ did not differ from the CSC mean $\left(1.65 \%=1,031\right.$ plants $\left.\mathrm{ha}^{-1}\right)$; the ESC means ranged from $0.0 \%$ to $17.49 \%\left(10,931\right.$ plants $\left.\mathrm{ha}^{-1}\right)$ and the CSC ranged from $0.0 \%$ to $6.90 \%\left(4,312\right.$ plants ha $\left.{ }^{-1}\right)$. Notice that 31 out of the 48 ESC (64.58\%) did not differ from the mean of the CSC, and that only two out of 48 ESC pre- 
sented higher plant lodging than the CSC with the highest plant lodging $(6.90 \%)$, and these two ESC were not among the ten highest yielding ESC (Table 1).

Plant height, ear height, and ear placement traits are regularly assessed in maize breeding programs since they are closely related to plant lodging; i.e., higher the plant height $(\mathrm{PH})$ and/or ear (EH) height and/or ear placement (EP) higher the probability of plant lodging. These traits presented similar pattern of variation as expected because they are highly correlated among themselves (Hallauer and Miranda Filho, 1988; Silva et al., 2004). For the three traits the ESC means did not differ from the CSC means, and individually most of the ESC $(\geq 67.0 \%)$ did not differ from the CSC mean. Notice that the ESC with the highest $\mathrm{PH}(227.39 \mathrm{~cm}$ per plant) differed from the CSC with the highest PH $(216.50 \mathrm{~cm}$ per plant), but the difference between them was not great enough $(10.89 \mathrm{~cm}$ per plant $=5.03 \%)$ to discard it as a potential cultivar. On the other hand, the ESC with the highest EH (131.95 cm per plant) differed from the CSC with the highest $\mathrm{EH}(120.00 \mathrm{~cm}$ per plant), and the difference between them $(11.95 \mathrm{~cm}$ per plant $=9.96 \%)$ was great enough to discard it as a potential cultivar. For ear placement, the mean of the ESC (0.52) was slightly lower but did not differ from the CSC (0.54), and about $85.00 \%$ of the ESC did not differ from the CSC; also the highest yielding ESC had an EP value of 0.52 (Table 1).

Prolificacy has been associated to drought stress tolerance (Campos et al., 2006) and to stability of maize hybrids across environments (Motto and Moll, 1983). Since in tropical maize growing areas short periods of lack of precipitation during the flowering time are frequent, and also because maize cultivated in off-growing season occupies a large area in Brazil nowadays where moisture stress is likely to occur, prolificacy should be considered as an important trait in breeding programs for these regions. The overall means for prolificacy for both ESC and CSC were equal (0.95); only eight (16.67\%) of the ESC presented more than 1.0 ears per plant and all CSC presented less than 1.0 ears per plant (Table 1). Hence, besides GY, PL and plant and ear heights traits that have been used for selecting the superior testcrosses, selection for prolificacy should be implemented in the MRRS program. Since it is a trait that presents high heritability in a single-plant basis (Hallauer and Miranda Filho, 1988), selection for prolificacy could be easily implemented during the development of the $\mathrm{S}_{3}$ lines.

If one considers that to be commercialized a SC should present at least the GY mean and the upper means for PL, PH, EH, EP, and PRO of the CSC evaluated, this hypothetical SC would have the following means: $9.86 \mathrm{t} \mathrm{ha}^{-1}, 6.90 \%$ of lodged plants, $216.50 \mathrm{~cm}$ per plant, $120.0 \mathrm{~cm}$ per plant, 0.56 as ear placement, and 0.95 ears per plant, respectively. Then, the ten highest yielding ESC will have superior performance than this SC, as the means of these ESC were $10.80 \mathrm{t} \mathrm{ha}^{-1}, 2.87 \%$ of lodged plants, $210.07 \mathrm{~cm}$ per plant, $107.51 \mathrm{~cm}$ per plant, 0.51 as ear placement, and 0.98 ears per plant. Further- more, as each one of these ESC compared favorably to the CSC they could be released commercially as cultivars. For instance, the highest yielding ESC presented the following values: $11.37 \mathrm{t} \mathrm{ha}^{-1}, 3.48 \%$ of lodged plants, $225.68 \mathrm{~cm}$ per plant, $117.57 \mathrm{~cm}$ per plant, 0.52 as EP, and 0.94 ears per plant. Thus, this ESC will present higher grain yield, less logged plants, about $9 \mathrm{~cm}$ higher plants, lower ear height plants, lower ear placement, and similar PRO than that hypothetical SC. However, for GY this ESC did not differ significantly from the highest yielding CSC (11.37 t ha ${ }^{-1}$ vs. $\left.11.46 \mathrm{t} \mathrm{ha}^{-1}\right)$.

Although the IG-3-C1 and IG-4-C1 synthetics have been improved effectively to develop SC that presented superior performances than several CSC, they have not been improved yet at such level to allow the development of SC that outperform the highest yielding CSC. These ESC were developed from $\mathrm{S}_{3}$ lines selected after only one cycle of the MRRS procedure. Hence, one could expect that after the recombination of the eight selected $\mathrm{S}_{3}$ lines from IG-3-C1 and of the six selected $\mathrm{S}_{3}$ lines from IG-4-C1 synthetics to develop the IG-3 cycle 2 (IG-3-C2) and IG-4 cycle 2 (IG-4-C2), these improved populations will have potential to develop single-crosses that outperform the highest yielding CSC, since the favorable alleles for the traits assessed that were dispersed among the $\mathrm{S}_{3}$ selected lines within each population should be assembled in genotypes that will be sources of higher performing single-crosses.

\section{General and specific combining ability}

RRS breeding procedure was designed to exploit both general (GCA) and specific (SCA) combining abilities, which are related, respectively, to additive and non-additive (dominance and epistasis) effects (Comstock et al., 1949). Thus it is important to know whether the relative contribution of these effects to the ESC expression have been altered by the RRS procedure used in this research. Highly significant $(p \leq 0.01)$ or significant $(p \leq 0.05)$ differences were detected for GCA for the lines of both populations (GCA-IG-3 and GCA-IG-4) for GY, PH, EH, and PRO; whereas for EP no difference was detected for GCA-IG4 and no differences were detected for PL for both GCA-IG-3 and GCA-IG-4 lines. Also, highly significant and significant differences were detected for specific combining ability (SCA) for all traits. Thus, additive and non-additive effects were detected for all traits, except for PL where only non-additive effects were detected. For the interactions with environments (E), highly significant and significant differences were detected for GCA $\times \mathrm{E}$ and $\mathrm{SCA} \times \mathrm{E}$ for GY, PL, and PRO; whereas for PH, EH and EP some of these effects did not differ significantly from zero. These results indicate that the CGA effects for the lines of both populations as well as the SCA effects for GY, PL, and PRO varied across the environments. For the remaining traits the results for the interactions were inconsistent (Table 2). For GY the estimates of GCA ranged from $-1.16 \mathrm{tha}^{-1}$ to $0.85 \mathrm{t} \mathrm{ha}^{-1}$, and for SCA the estimates ranged from $-4.61 \mathrm{t} \mathrm{ha}^{-1}$ to 
Table 1 - Mean values, least significant differences and experimental coefficients of variation for the experimental maize single-crosses and checks for several traits.

\begin{tabular}{|c|c|c|c|c|c|c|c|}
\hline \multicolumn{2}{|c|}{ Crosses } & Grain yield & Plant lodging & Plant height & Ear height & Ear placement & Prolificacy \\
\hline \multirow{7}{*}{$31 \mathrm{x}$} & & $\mathrm{t} \mathrm{ha}^{-1}$ & plants ha-1 & cm per & plant & & ears per plant \\
\hline & 41 & 9.02 & 3570 & 211.23 & 112.00 & 0.53 & 0.90 \\
\hline & 42 & 9.86 & 473 & 218.39 & 109.79 & 0.50 & 0.95 \\
\hline & 43 & 9.97 & 227 & 227.20 & 123.43 & 0.54 & 0.91 \\
\hline & 44 & 9.88 & 10933 & 226.80 & 120.91 & 0.53 & 0.97 \\
\hline & 45 & 11.37 & 2172 & 225.68 & 117.57 & 0.52 & 0.94 \\
\hline & 46 & 9.88 & 500 & 210.48 & 110.02 & 0.52 & 0.92 \\
\hline \multirow{6}{*}{$32 x$} & 41 & 9.41 & 1901 & 198.68 & 98.13 & 0.49 & 0.97 \\
\hline & 42 & 9.09 & 518 & 201.96 & 102.84 & 0.51 & 0.94 \\
\hline & 43 & 3.10 & 2529 & 182.45 & 93.71 & 0.51 & 0.32 \\
\hline & 44 & 9.24 & 1285 & 212.85 & 110.08 & 0.52 & 0.95 \\
\hline & 45 & 11.13 & 1161 & 211.11 & 98.91 & 0.47 & 1.00 \\
\hline & 46 & 8.51 & 490 & 198.82 & 101.04 & 0.51 & 0.87 \\
\hline \multirow{6}{*}{$33 x$} & 41 & 9.12 & 450 & 188.88 & 97.80 & 0.51 & 0.93 \\
\hline & 42 & 10.09 & 1550 & 205.71 & 104.13 & 0.50 & 0.90 \\
\hline & 43 & 10.70 & 3135 & 212.14 & 111.27 & 0.52 & 0.92 \\
\hline & 44 & 10.92 & 5126 & 212.43 & 109.30 & 0.51 & 1.03 \\
\hline & 45 & 10.61 & 2353 & 208.70 & 103.80 & 0.50 & 0.94 \\
\hline & 46 & 9.03 & 949 & 206.48 & 106.54 & 0.51 & 0.86 \\
\hline \multirow{6}{*}{$34 x$} & 41 & 9.09 & 2312 & 205.13 & 120.84 & 0.59 & 0.99 \\
\hline & 42 & 9.34 & 2149 & 223.79 & 130.68 & 0.58 & 1.00 \\
\hline & 43 & 9.64 & 2339 & 222.70 & 126.36 & 0.57 & 1.01 \\
\hline & 44 & 9.36 & 1262 & 227.39 & 131.95 & 0.58 & 1.10 \\
\hline & 45 & 10.07 & 1104 & 214.21 & 121.54 & 0.57 & 0.99 \\
\hline & 46 & 9.69 & 1618 & 211.80 & 121.16 & 0.57 & 0.97 \\
\hline \multirow{6}{*}{$35 \mathrm{x}$} & 41 & 9.08 & 902 & 204.57 & 103.27 & 0.51 & 1.04 \\
\hline & 42 & 10.40 & 1303 & 213.59 & 106.89 & 0.50 & 1.01 \\
\hline & 43 & 10.16 & 1550 & 218.79 & 112.38 & 0.51 & 0.94 \\
\hline & 44 & 9.43 & 947 & 217.71 & 115.55 & 0.53 & 0.94 \\
\hline & 45 & 10.37 & 582 & 214.29 & 106.79 & 0.50 & 1.00 \\
\hline & 46 & 9.27 & 2015 & 204.38 & 106.96 & 0.52 & 0.96 \\
\hline \multirow{6}{*}{$36 x$} & 41 & 8.83 & 3713 & 190.88 & 99.73 & 0.52 & 1.00 \\
\hline & 42 & 9.42 & 1266 & 203.05 & 110.29 & 0.54 & 0.92 \\
\hline & 43 & 8.65 & 1790 & 211.29 & 113.82 & 0.54 & 0.86 \\
\hline & 44 & 9.78 & 3399 & 197.41 & 108.68 & 0.55 & 0.95 \\
\hline & 45 & 9.98 & 1570 & 198.61 & 104.09 & 0.52 & 1.00 \\
\hline & 46 & 8.65 & 2249 & 191.37 & 100.62 & 0.53 & 0.92 \\
\hline \multirow{6}{*}{$37 x$} & 41 & 9.12 & 0 & 200.09 & 103.63 & 0.52 & 0.94 \\
\hline & 42 & 9.63 & 0 & 208.18 & 111.13 & 0.53 & 0.91 \\
\hline & 43 & 9.54 & 990 & 214.98 & 116.95 & 0.54 & 1.00 \\
\hline & 44 & 9.61 & 1764 & 210.36 & 110.98 & 0.53 & 1.00 \\
\hline & 45 & 10.23 & 29 & 210.11 & 108.25 & 0.52 & 0.90 \\
\hline & 46 & 9.24 & 1947 & 198.07 & 105.18 & 0.53 & 0.95 \\
\hline \multirow{6}{*}{$38 x$} & 41 & 11.27 & 189 & 190.93 & 110.14 & 0.57 & 0.95 \\
\hline & 42 & 9.13 & 228 & 192.75 & 95.13 & 0.49 & 0.88 \\
\hline & 43 & 9.23 & 1576 & 199.43 & 103.75 & 0.52 & 1.02 \\
\hline & 44 & 11.04 & 1867 & 201.73 & 102.14 & 0.51 & 1.06 \\
\hline & 45 & 9.63 & 892 & 188.93 & 92.43 & 0.49 & 0.96 \\
\hline & 46 & 9.77 & 2132 & 196.63 & 99.89 & 0.51 & 1.02 \\
\hline \multirow{2}{*}{ Means } & & 9.57 & 1729 & 207.15 & 109.01 & 0.52 & 0.95 \\
\hline & & {$[3.10 ; 11.37]^{a}$} & {$[0 ; 10993]$} & {$[182.45 ; 227.39]$} & {$[92.43 ; 131.95]$} & {$[0.47 ; 0.59]$} & {$[0.32 ; 1.10]$} \\
\hline \multicolumn{2}{|l|}{ Check Means } & $\begin{array}{c}9.86 \\
{[8.25 ; 11.46]}\end{array}$ & $\begin{array}{c}1029 \\
{[0 ; 4311]}\end{array}$ & $\begin{array}{c}201.79 \\
{[185.41 ; 216.50]}\end{array}$ & $\begin{array}{c}108.29 \\
{[93.24 ; 120.00]}\end{array}$ & $\begin{array}{c}0.54 \\
{[0.50 ; 0.56]}\end{array}$ & $\begin{array}{c}0.95 \\
{[0.95 ; 0.95]}\end{array}$ \\
\hline \multirow{2}{*}{\multicolumn{2}{|c|}{$\begin{array}{l}\text { LSD (5\%) } \\
\text { CV }(\%)\end{array}$}} & 1.26 & 810 & 9.65 & 8.55 & 0.03 & 0.12 \\
\hline & & 12.06 & 62.46 & 4.61 & 7.02 & 5.19 & 8.29 \\
\hline
\end{tabular}

${ }^{\mathrm{a}}$ Range intervals. ${ }^{\mathrm{b}}$ Least significant differences at the 0.05 probability level. 
$1.87 \mathrm{t} \mathrm{ha}^{-1}$; notice that the estimates of SCA were larger than the GCA estimates. Also, for PL and PRO the ranges and estimates of the SCA were larger than the GCA estimates. For PH, EH, and EP the ranges and estimates of the GCA and SCA effects presented similar values (Tables 3 and 4).

The relative contribution of the GCA and SCA effects for the ESC variation was $37.34 \%$ and $62.66 \%$ for GY, $39.14 \%$ and $60.86 \%$ for PL, and $34.38 \%$ and $65.62 \%$ for PRO. For the remaining traits the CGA contribution was higher $(>78.0 \%)$ than the SCA contribution for the ESC variation. Thus, the non-additive effects (dominance and epistasis) were more important than the additive effects for GY, PL, and PRO, whereas for PH, EH, and EP the contribution of the additive effects were more important than the non-additive effects for the ESC variation. The relative importance of GCA over SCA de- pends on the level of dominance of the trait. For instance, reported results have shown that the level of dominance for GY ranged from partial to complete dominance, and for $\mathrm{PH}$ it ranged from additive to partial dominance (Bingham, 1998; Silva et al., 2004), and then one could expect that SCA was as important as GCA effect for GY, and that GCA was more important than SCA effect for PH. In fact, GCA effect is as important as SCA effect for GY, and GCA is more important than SCA for PH (Hallauer and Miranda Filho, 1988; Aguiar et al., 2003). However, to some extent, the type of selection applied could affect the relative importance of these effects (Doerksen et al., 2003; Santos et al., 2007). Santos et al. (2007) reported that after three cycles of RRS the relative importance of GCA over SCA changed, since the SCA values increased more than the GCA values for GY across the cycles, and thus the SCA effects became

Table 2 - Values and significances of the means squares from the diallel analyses of variance, and contributions of general (GCA) and specific (SCA) combining ability for traits expression for several maize traits.

\begin{tabular}{|c|c|c|c|c|c|c|c|}
\hline Sources of variation & DF & Grain yield & Plant lodging & Plant height & Ear height & Ear placement ${ }^{a}$ & Prolificacy $^{\mathrm{b}}$ \\
\hline & & $\mathrm{t} \mathrm{ha}^{-1}$ & $\%$ & \multicolumn{2}{|c|}{ cm per plant } & & ears per plant \\
\hline Environments (E) & 5 & $192.53 * *$ & $37.17 * *$ & $22034.48 * *$ & $11099.40 * *$ & $23.17 * *$ & $40.68^{* *}$ \\
\hline Crosses (C) & 47 & $16.86 \%$ & $3.24 * *$ & $986.01 * *$ & $675.45 \%$ & $5.48 \% *$ & $6.82 \% *$ \\
\hline GCA (IG3) & 7 & $22.07 * *$ & $4.26^{\mathrm{ns}}$ & $3795.91 \%$ & $3238.78 *$ & $25.19 * *$ & $9.44 * \%$ \\
\hline GCA (IG4) & 5 & $28.29 * \%$ & $5.95^{\text {ns }}$ & $1954.12 * *$ & $753.09 *$ & $5.08^{\mathrm{ns}}$ & $8.81 \%$ \\
\hline SCA & 35 & $14.18 \%$ & $2.65 \%$ & $285.73 * \%$ & $151.69 * *$ & $1.60 *$ & $6.01 \% *$ \\
\hline $\mathrm{C} \times \mathrm{E}$ & 235 & $2.47 * *$ & $1.83 \% *$ & $95.16^{\mathrm{ns}}$ & $74.72^{\mathrm{ns}}$ & $1.15^{* *}$ & $1.14^{* *}$ \\
\hline GCA $(\mathrm{IG} 3) \times \mathrm{E}$ & 35 & $3.83 \% *$ & $2.24 \% *$ & $101.80^{\mathrm{ns}}$ & $53.68^{\mathrm{ns}}$ & $0.81^{\mathrm{ns}}$ & $1.37 *$ \\
\hline GCA $(\mathrm{IG} 4) \times \mathrm{E}$ & 25 & $3.63 \%$ & $2.66 \% *$ & $91.95^{\mathrm{ns}}$ & $185.55^{* *}$ & $2.63 \% *$ & $1.41 \%$ \\
\hline $\mathrm{SCA} \times \mathrm{E}$ & 175 & $2.03 * *$ & $1.62 *$ & $94.29^{\mathrm{ns}}$ & $63.09^{\mathrm{ns}}$ & $1.01 \%$ & $1.05 \%$ \\
\hline Error & 216 & 1.33 & 1.12 & 91.10 & 58.60 & 0.74 & 0.61 \\
\hline GCA (\%) & & 37.34 & 39.14 & 78.42 & 83.28 & 78.30 & 34.38 \\
\hline SCA (\%) & & 62.66 & 60.86 & 21.58 & 16.72 & 21.70 & 65.62 \\
\hline
\end{tabular}

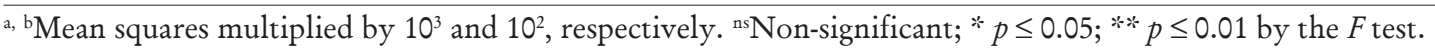

Table 3 - General $\left(\hat{g}_{i}\right.$ and $\left.\hat{g}_{j}\right)$ and specific $\left(\hat{s}_{i j}\right)$ combining ability estimates from the diallel analysis for maize grain yield $\left(\mathrm{tha}^{-1}\right)$.

\begin{tabular}{|c|c|c|c|c|c|c|c|}
\hline \multirow{2}{*}{ Inbred lines } & 41 & 42 & 43 & 44 & 45 & 46 & \multirow{2}{*}{$\hat{g}_{i}$} \\
\hline & \multicolumn{6}{|c|}{$\hat{S}_{i j}$} & \\
\hline 31 & $-0.77 \%$ & $-0.18^{\mathrm{ns}}$ & $0.68 \% *$ & $-0.45 \%$ & $0.53 \% *$ & $0.20 *$ & $0.42 * *$ \\
\hline 32 & $1.21 \% *$ & $0.63 \% *$ & $-4.61 \% *$ & $0.49 * *$ & $1.87 * *$ & $0.41 \% *$ & $-1.16 * *$ \\
\hline 33 & $-0.75 \% *$ & $-0.04^{\mathrm{ns}}$ & $1.32 \% *$ & $0.51 \% *$ & $-0.32 * *$ & $-0.73 * *$ & $0.50 * *$ \\
\hline 34 & $-0.23 *$ & $-0.23 \%$ & $0.81 \% *$ & $-0.51 * *$ & $-0.31 * *$ & $0.48 * *$ & $-0.04^{\mathrm{ns}}$ \\
\hline 35 & $-0.50 * *$ & $0.57 * *$ & $1.08 \% *$ & $-0.69 * *$ & $-0.26 * *$ & $-0.20 *$ & $0.21^{\text {ns }}$ \\
\hline 36 & $-0.18 *$ & $0.16^{\mathrm{ns}}$ & $0.13^{\mathrm{ns}}$ & $0.23 *$ & $-0.09^{\mathrm{ns}}$ & $-0.25 \%$ & $-0.36 \% *$ \\
\hline 37 & $-0.23 *$ & $0.02^{\text {ns }}$ & $0.68 \% *$ & $-0.28 * *$ & $-0.18 \%$ & $0.00^{\text {ns }}$ & $-0.01^{\mathrm{ns}}$ \\
\hline 38 & $1.46 \%$ & $-0.93 \%$ & $-0.08^{\mathrm{ns}}$ & $0.69 * *$ & $-1.23 \%$ & $0.08^{\mathrm{ns}}$ & $0.44 * *$ \\
\hline$\hat{g}_{j}$ & $-0.21^{\mathrm{ns}}$ & $0.05^{\text {ns }}$ & $-0.70 \% *$ & $0.33 \%$ & $0.85 \%$ & $-0.32 \%$ & \\
\hline
\end{tabular}

${ }^{n}$ Non-significant; " $p \leq 0.05 ; " * 0.0 .01$ by the $t$ test. 
Table 4 - General $\left(\hat{g}_{i}\right.$ and $\left.\hat{g}_{j}\right)$ and specific $\left(\hat{s}_{i j}\right)$ combining ability estimates from the diallel analysis for maize plant lodging (PL) and ear placement (EP).

\begin{tabular}{|c|c|c|c|c|c|c|c|c|c|c|c|c|c|c|}
\hline \multirow{3}{*}{$\begin{array}{l}\text { Inbred } \\
\text { lines }\end{array}$} & \multicolumn{2}{|c|}{41} & \multicolumn{2}{|c|}{42} & \multicolumn{2}{|c|}{43} & \multicolumn{2}{|c|}{44} & \multicolumn{2}{|c|}{45} & \multicolumn{2}{|c|}{46} & \multirow{2}{*}{\multicolumn{2}{|c|}{$\hat{g}_{i}$}} \\
\hline & \multicolumn{12}{|c|}{$\hat{s}_{i j}$} & & \\
\hline & PL & $\mathrm{EP}^{\mathrm{a}}$ & PL & EP & PL & EP & PL & EP & PL & EP & PL & EP & PL & EP \\
\hline 31 & $0.59 \% *$ & $0.10^{\mathrm{ns}}$ & $-0.52 \% *$ & $-2.00 * *$ & $-1.14 * *$ & $1.10 \% *$ & $1.71 * *$ & $0.00^{\text {ns }}$ & $0.18^{\mathrm{ns}}$ & $1.00 \% *$ & $-0.81 \% *$ & $-0.20^{\mathrm{ns}}$ & $0.29 *$ & $0.00^{\text {ns }}$ \\
\hline 32 & $0.39 * *$ & $-1.30 \% *$ & $-0.07^{\mathrm{ns}}$ & $1.00 \% *$ & $0.48 * *$ & $0.60 *$ & $-0.52 * *$ & $0.80 \% *$ & $0.14^{\mathrm{ns}}$ & $-1.90 \% *$ & $-0.41 * *$ & $0.80 * *$ & $-0.12^{\text {ns }}$ & $-2.40 * \%$ \\
\hline 33 & $-0.75^{* * *}$ & $-0.40^{\mathrm{ns}}$ & $0.14^{\mathrm{ns}}$ & $-0.10^{\mathrm{ns}}$ & $0.33^{* * *}$ & $0.50^{\mathrm{ns}}$ & $0.47^{* * *}$ & $-0.60 \%$ & $0.30 * *$ & $0.20^{\text {ns }}$ & $-0.48 \% *$ & $0.30^{\mathrm{ns}}$ & $0.24^{\mathrm{ns}}$ & $-1.40 \% *$ \\
\hline 34 & $0.31 \%$ & $0.80 \% *$ & $0.51 \% *$ & $1.10 \% *$ & $0.15^{\mathrm{ns}}$ & $-1.70 \% \%$ & $-0.79 \% *$ & $-0.20^{\text {ns }}$ & $-0.15^{\mathrm{ns}}$ & $0.60 *$ & $-0.04^{\mathrm{ns}}$ & $-0.60 \%$ & $0.13^{\text {ns }}$ & $5.10 \% *$ \\
\hline 35 & $-0.07^{\mathrm{ns}}$ & $-1.10 * *$ & $0.41 \% *$ & $-0.80 * *$ & $0.10^{\text {ns }}$ & $-0.60 *$ & $-0.67 * *$ & $1.40 * *$ & $-0.18^{\mathrm{ns}}$ & $0.20^{\text {ns }}$ & $0.42 * *$ & $0.90 * *$ & $-0.15^{\mathrm{ns}}$ & $-1.30 * *$ \\
\hline 36 & $0.59 \% *$ & $-1.80 \% \%$ & $-0.09^{\mathrm{ns}}$ & $1.30 \% *$ & $-0.28 *$ & $-0.40^{\mathrm{ns}}$ & $-0.14^{\mathrm{ns}}$ & $1.00 \% *$ & $-0.12^{\mathrm{ns}}$ & $0.60 *$ & $0.03^{\mathrm{ns}}$ & $-0.70 * *$ & $0.33 *$ & $0.80 \% *$ \\
\hline 37 & $-0.56^{* * *}$ & $-1.50 \% *$ & $-0.19^{\text {ns }}$ & $0.90 \% *$ & $0.18^{\text {ns }}$ & $0.70 * *$ & $0.09^{\text {ns }}$ & $-0.80 \% *$ & $-0.27 *$ & $0.30^{\mathrm{ns}}$ & $0.75^{* \%}$ & $0.30^{\text {ns }}$ & $-0.51 \% *$ & $0.30^{\mathrm{ns}}$ \\
\hline 38 & $-0.49 * *$ & $5.20 \% *$ & $-0.19^{\mathrm{ns}}$ & $-1.50 \% *$ & $0.19^{\mathrm{ns}}$ & $-0.30^{\mathrm{ns}}$ & $-0.15^{\mathrm{ns}}$ & $-1.50 \% *$ & $0.10^{\text {ns }}$ & $-1.00 * *$ & $0.54 * *$ & $-0.80 * *$ & $-0.23^{\text {ns }}$ & $-1.10 * x$ \\
\hline$\hat{g}_{j}$ & $-0.08^{\text {ns }}$ & $0.60^{\mathrm{ns}}$ & $-0.35^{*}$ & $-0.50^{\mathrm{ns}}$ & $0.08^{\mathrm{ns}}$ & $0.70^{\text {ns }}$ & $0.55 \% *$ & $0.70^{\text {ns }}$ & $-0.17^{\mathrm{ns}}$ & $-1.50 \% *$ & $-0.03^{\text {ns }}$ & $0.00^{\text {ns }}$ & & \\
\hline
\end{tabular}

${ }^{a}$ Estimates multiplied by $10^{2}$. ${ }^{\text {nn }}$ Non-significant; $" p \leq 0.05 ;{ }^{* *} p \leq 0.01$ by the $t$ test.

more important than GCA effects. This change was attributable to the type of selection applied since selection for GY was based on the means of interpopulation progenies, emphasizing the performance of the crosses. On the other hand, for $\mathrm{PH}$ the relative importance of GCA over SCA did not change with selection since the selection for this trait was practiced during the development of progenies; i.e., intrapopulation selection was used for PH. Similar results on the increase of the relative importance of non-additive effects (SCA) over additive effects (SCA) on the crosses of maize populations under RRS for GY were also reported by Doerksen et al. (2003).

Comparing with those reported our results suggest that the RRS procedure used also changed the relative contribution of GCA over SCA for GY, PL, and PRO, since the contribution of the non-additive effects (SCA) were more important than the additive effects (GCA) for the ESC variation. Selection for GY and PL was based on interpopulation progenies, whereas no selection was practiced for PRO. However since PRO is an important GY component, the interpopulation selection for GY could have caused an indirect response for PRO changing the relative importance of GCA over SCA for this trait. For plant height, ear height, and ear placement traits, selection was practiced mainly during the development of the $\mathrm{S}_{3}$ lines, i.e., at intrapopulation level emphasizing the additive effects, and then, as expected, no changes on the relative importance of the GCA over SCA were observed. Thus, our results were in agreement with those reported by Santos et al. (2007) and Doerksen et al. (2003).

\section{Implications for breeding}

The modifications implemented in the RRS program reported in this study; i.e., high selection intensity $(\approx 2.0 \%)$ coupled with the evaluation of testcrosses and recombination of $\mathrm{S}_{3}$ lines, developed populations (IG-3$\mathrm{C} 1$ and IG-4-C1) that were improved at such level that the ESC developed from them compared favorably with CSC. Therefore, the MRRS procedure outlined and evaluated in this research could be used effectively in maize breeding programs to fulfill both the need to increase or maintain the genetic variability of the pedigree programs and to release outstanding single-crosses as cultivars. These ESC represent the effects of only one cycle of selection, and then after the recombination of the selected lines the improved second-cycle populations will be, probably, sources of inbred lines whose singlecrosses should outperform the best CSC. The modifications outlined in the original RRS procedure could be used not only for the maize crop, but also for all crop species in which hybrids are used as cultivars; e.g., sunflower and sorghum.

Non-additive effects (dominance and epistasis) were more important than additive effects for GY and PL which are the main traits in maize breeding programs, and that these results could be attributed to the effects of the RRS. Positive and high SCA values were associated to higher yielding ESC; e.g., the three highest yielding ESC presented SCA estimates that ranged from 1.32 to $1.87 \mathrm{t} \mathrm{ha}^{-1}$, showing that dominance and epistatic effects are more important than additive effects for the development of outstanding SC. Thus, selection for these traits could only be based on the means of single-crosses assessed in several locations and years, since the SCA effects were more important than GCA effects for GY and PL, and SCA effects interacted significantly with environments,

\section{References}

Aguiar, A.M.; Carlini-Garcia, L.A.; Silva, A.R.; Santos, M.F; Garcia, A.A.F.; Souza Jr., C.L. 2003. Combining ability of inbred lines of maize and stability of their respective single-crosses. Scientia Agricola 60: 83-89.

Bernardo, R. 1991. Correlation between testcross performance of lines at early and late selfing generations. Theoretical and Applied Genetics 82: 17-21. 
Bernardo, R. 1996. Testcross selection prior to further inbreeding in maize: mean performance and realized genetic variance. Crop Science 36: 867-871.

Bernardo, R. 2002. Breeding for quantitative traits in plants. Stemma Press, Woodbury, MN, USA.

Betrán, F.J.; Hallauer, A.R. 1996. Hybrid improvement after reciprocal recurrent selection in BSSS and BSCB1 maize populations. Maydica 41: 24-33.

Bingham, E.T. 1998. Role of chromosome blocks in heterosis and estimates of dominance and overdominance. p. 71-87. In: Lamkey, K.R.; Staub, J.E., eds. Concepts and breeding of heterosis in crop plants. American Society of Crop Science, Madison, WI, USA.

Campos, H.; Cooper, M.; Edemeades, G.O.; Loffler, J.R.; Schussler, J.R.; Ibãnez, M. 2006. Changes in drought tolerance in maize associated with fifty years of breeding for yield in the U.S. corn belt. Maydica 51: 369-381.

Comstock, R.E; Robinson, H.F; Harvey, P.H. 1949. A breeding procedure designed to make maximum use of both general and specific combining ability. Agronomy Journal 41: 360-367.

Doerksen, T.K.; Kannenberg, L.W.; Lee, E.A. 2003. Effect of recurrent selection on combining ability in maize breeding populations. Crop Science 43: 1652-1658.

Eyherabide, G.H.; Hallauer, A.R. 1991. Reciprocal full-sib recurrent selection. I. Direct and correlated responses. Crop Science 31: 952-959.

Ferreira, D.F.; Rezende, G.D.S.P.; Ramalho, M.A.P. 1993. An adaptation of Griffing's method IV of complete diallel cross analysis for experiments repeated in several environments. Brazilian Journal of Genetics 16: 357-366.

Geraldi, I.O., Miranda Filho, J.B. 1988. Adapted models for the analysis of combining ability of varieties in partial diallel crosses. Brazilian Journal of Genetics 11: 419-430.

Griffing, B. 1956. Concept of general and specific combining ability in relation to diallel crossing systems. Australian Journal of Biological Science 9: 463-493.

Hallauer, A.R. 1990. Methods used in developing maize inbreds. Maydica 35: 1-16.

Hallauer, A.R.; Miranda Filho, J.B. 1988. Quantitative genetics in maize breeding. Iowa State University Press, Ames, IA, USA.
Hallauer, A.R.; Russell, W.W; Lamkey, K.R. 1988. Corn breeding. p. 941-963. In: Sprague, G.F.; Dudley, J.W., eds. Corn and corn improvement. American Society of Agronomy, Madison, WI, USA.

Motto, M.; Moll, RH. 1983. Prolificacy in maize: a review. Maydica 28: $53-76$.

Rezende, G.S.P.; Souza Jr., C.L. 2000. A reciprocal recurrent selection procedure outlined to integrate hybrid breeding programs in maize. Journal of Genetics \& Breeding 54: 57-66.

SAS Institute 2004. SAS ${ }^{\circledast}$ proprietary software, version 9.12. SAS Institute,. Cary, NC, USA.

Santos, M.F.; Moro, G.V.; Aguiar, A.M.; Souza Jr., C.L. 2005. Responses to reciprocal recurrent selection and changes in genetic variability in IG-1 and IG-2 maize populations. Genetics and Molecular Biology 28: 781-788.

Santos, M.F.; Câmara, T.M.M.; Moro, G.V.; Costa, E.F.N.; Souza Jr., CL. 2007. Responses to selection and changes in combining ability after three cycles of a modified reciprocal recurrent selection in maize. Euphytica 157: 185-194.

Silva, A.R.; Souza Jr., C.L.; Aguiar, A.M.; Souza, A.P. 2004. Estimates of genetic variance and level of dominance in a tropical maize population. I. Grain yield and plant traits. Maydica 49: 65-71.

Smith, J.C.S. 1988. Diversity of United States hybrid maize Germplasm: isozymic and chromatographic evidence. Crop Science 28: 63-69.

Sokal, R.R.; Rohlf, F.J. 1995. Biometry. W.H. Freeman, New York, NY, USA.

Souza Jr., C.L.; Santos, M.X.; Magnavaca, R.; Gama, E.E.G. 1993. Estimates of genetic parameters in the maize interpopulation BR-105 x BR-106 and implications in breeding. Pesquisa Agropecuária Brasileira 28: 473-479

Souza Jr., C.L.; Pinto, R.M.C. 2000. Responses to a short-term reciprocal recurrent selection procedure in maize. Maydica 45: 21-28.

Yu, J.; Bernardo, R. 2004. Changes in genetic variance during advanced cycle breeding in maize. Crop Science 44: 405-410.

Received April 17, 2009

Accepted December 22, 2009 